\title{
An Analysis of the Commonly Occurring Fungal Populations in Water, Sediment and the Fish (Glossogobius giuris) at Lower Anicut, Thanjavur District, Tamil Nadu, India
}

\author{
P. Balasubramanian ${ }^{1}$ and R. Sivakami ${ }^{2 *}$ \\ ${ }^{1}$ Department of Zoology, Government Arts College (Autonomous), Kumbakonam-612 002, \\ Tamil Nadu, India \\ ${ }^{2}$ Department of Zoology, Arignar Anna Govt. Arts College, Musiri-621211, Tamil Nadu, India \\ *Corresponding author
}

\section{A B S T R A C T}

\begin{tabular}{|l|}
\hline Ke y w o r d s \\
$\begin{array}{l}\text { Fresh water, Sediment, } \\
\text { Fungal species, } \\
\text { Glossogobius giuris }\end{array}$ \\
\hline Article Info \\
\hline $\begin{array}{l}\text { Accepted: } \\
\text { 28 May } 2018 \\
\text { Available Online: } \\
\text { 10 July } 2018\end{array}$ \\
\hline
\end{tabular}

\section{Introduction}

Today aquaculture contributes a great deal to the national productivity, socio-economic development and renewable aquatic living resources (Ramaiah, 2006). However, diseases can cause huge economic losses in aquaculture and fungal infections are second only to bacterial diseases in economic importance (Meyer, 1991). According to Bangyeekhun and Sylvie (2001) fungi can attack fish in all its life stages in both wild as well as commercial fish farms. Chukanhom and Hatai (2004) reported that the mortality rate of incubated eggs due to fungal infections can reach $100 \%$. Hence, it is imperative to address this issue immediately. In India, records on mycotic infections are limited and in many instances missing (Ramaiah, 2006).

India, today ranks second in aquaculture production and any fungal attack on farm fishes can cause devastation to the Indian farmers besides leading to a decrease in aquaculture production. Hence, a study was attempted to identify the fungi present in water, sediment as well as in Glossogobius giuris collected from Lower Anicut, Anakkarai village, Thiruppanandal Block in Thanjavur District, Tamil Nadu, India. 


\section{Materials and Methods}

\section{Site of collection}

For the present investigation, the samples were collected from the River Cauvery, Lower Anicut, Thanjavur District, Tamil Nadu. This riverhas a rich source of fish diversity with a variety of fishes like murrels, cat fish, carps and eels.

\section{Collection of Sample}

Samples of soil, water and the Indian freshwater sand gobi (Glossogobius giuris) were collected from January to February 2018 from Lower Anicut. The water and soil samples were taken in plastic containers kept in an ice box and brought to the laboratory.

Glossogobius giuris were collected in containers and brought to the laboratory in live condition. The weight and length of the fishes were recorded to determine the lengthweight relationship. The fish were dissected and the tissues of skin, foregut, mid gut and hindguts were taken separately.

\section{Identification and colony counting of fungi}

Fungi grow comparatively at slow rates, requiring several days to weeks; fungi produce spores on brightly coloured aerial hyphae. Most fungi grow best at room temperature (25 ${ }^{\circ} \mathrm{C}$ ) rather than $35{ }^{\circ} \mathrm{C}$. The basic medium for the culture of many fungi is potato dextrose agar (PDA).

After sterilization, the medium was poured into sterilized petridishes quickly under aseptic conditions. The petriplates were marked as control, soil, water, skin, foregut, midgut and hindgut. Before the medium was poured to the petriplates, a pinch of streptomycin was added to the medium to avoid bacterial growth. Preparation of
Different Dilution of the sample was done by the Serial Dilution Method.

\section{Inoculation}

The seven petriplates with the solidified agar were marked as control $10^{-1}, 10^{-2}, 10^{-3}, 10^{-4}$, $10^{-5}, 10^{-6}$ dilutions. Inoculation was done with the help of micropipette inside the inoculation chamber. The diluted sample was taken with the help of microculture medium into the culture plates. Each plate was rotated slowly to avoid splashing and mixing the organisms uniformly. The same process was repeated to inoculate the remaining six plates. After the inoculation, all the inoculated petriplates and control petriplates were placed in the culture chamber for 6-7 days at room temperature $\left(25^{\circ}\right)$ for the its growth.

In addition, seven petriplates with solidified PDA medium were also taken and marked as control, soil, water, epidermis, foregut, midgut and hindgut. Inoculation was done with help of micro pipette. Diluted samples from $10^{-4}$ dilution were taken and transferred to the petriplate containing the medium.

These were placed in the culture medium chamber for 6-7 days at room temperature (25 $\left.{ }^{\circ} \mathrm{C}\right)$ for its growth. Similar procedure was adopted for the other samples.

\section{Colony counting}

The well-developed fungal colonies were counted directly with the help of counting chamber andthe average number of the fungal colonies were recorded in each sample.

\section{Isolation of fungi}

Using a dissecting needle, a tuft of the fungi was taken from the culture to the slide and staining was done for identification purpose. 
Table.1 Existence of fungal flora in various samples of sand Gobi (Glossogobius giuris) and in water and soil

\begin{tabular}{|c|c|c|c|c|c|c|c|}
\hline \multirow[t]{2}{*}{ S. No. } & \multirow[t]{2}{*}{ Name of the Fungi } & \multicolumn{6}{|c|}{ Name of the Samples } \\
\hline & & Soil & Water & Epidermis & Foregut & Midgut & Hindgut \\
\hline 1. & Pencilliumcitrinum & + & - & + & - & - & + \\
\hline 2. & Pencilliumjanthinellum & + & - & - & + & + & + \\
\hline 3. & Pencilliumlanosum & - & + & + & - & - & - \\
\hline 4. & Aspergillus apicalis & + & + & - & + & + & - \\
\hline 5. & Aspergillus flavus & - & - & + & - & - & + \\
\hline 6. & Aspergillus sutagimuf & - & + & - & + & - & - \\
\hline 7. & Aspergillus luchensis & + & - & + & - & + & - \\
\hline 8. & Aspergillus terrus & + & + & - & - & - & - \\
\hline 9. & Aspergillus sydowi & + & + & - & + & - & - \\
\hline 10. & Aspergillus ustus & - & + & + & - & + & - \\
\hline 11. & Aspergillus nidulans & + & - & - & - & - & - \\
\hline 12. & Aspergillus niger & + & + & + & - & + & + \\
\hline 13. & Fusarium oxysporum & + & - & - & + & - & - \\
\hline 14. & Alternaria alternata & + & - & - & - & - & - \\
\hline 15. & Pullaviasp. & + & + & - & - & - & - \\
\hline 16. & Syncephalastriumsp. & - & + & + & - & - & - \\
\hline 17. & Rhizopus nigricans & - & + & - & + & + & + \\
\hline 18. & Dreschlerasp. & - & + & - & - & - & - \\
\hline
\end{tabular}

+ denotes present; - denotes absent. 


\section{Staining of fungi}

Fungi were stained with lactophenol cotton blue stain. After staining, the structure of the fungus was photographed under a Nikon microscope.The isolated fungi were identified with the help of available literature (Raper and Thom, 1949; Gilman, 1957; Barnett, 1962; Barron, 1986; Barnett and Hunter, 1986; Ellis, 1971, 1976; Subramanian, 1971; Ainsworth et al., 1973; Booth, 1977; Domsch et al., 1980; Van der Plaats-Niterink, 1981; Von Arx, 1981; Stolk and Samson, 1983; Schipper, 1984).

\section{Results and Discussion}

The various fungal species identified in water, sediment and fish (Glossogobius giuris) are presented in the Table-1. A total of 18 fungal species belonging to eight genera could be identified. Among this, the genus Aspergillus was represented by nine species and the genus Penicillium by three species. The remaining genera were represented by a single species.

A perusal of the fungal species in sediment and water reveals that both the sediment and water recorded 11 species each. However, the sediment recorded six species which were unique $(P$. citrinum, $P$. janthinellum, $A$. luchensis, A. nidulans, $F$. oxysporum and $A$. alternata) while the water samples recorded six unique species $(P$. lanosum, A. sutagimuf, $A$. ustus, $S$. sporangiophores, $R$. nigricans and D. spicifera) which were not recorded in sediment. Nevertheless, both the water and sediments recorded four species which was common (A. terrus, A. sydowi, A. nigerand A. fumigatus).

The skin of eel recorded the presence of seven fungi. The foregut recorded the presence of six species of fungi. Out of these, three species were unique and not recorded in the midgut and huntgut (A. fumigatus, A. sydowi and $F$. oxysporum). The midgut also recorded the presence of six species of which two were unique (A. luchensis and A. ustus) while the hindgut recorded the presence of five species of which only two were unique $(P$. citrinum and A. flavus).

Comparing the gut flora reveals that two species were common to all parts of the gut $(P$. janthinellum and $R$. nigricans). In addition, the foregut and midgut recorded one species (A. flavus) which was not recorded in the hindgut while the midgut and kindgut also recorded a species (A. niger) which was not recorded in the foregut. Interestingly, two species ( $P$. lanosum and D. spicifera) were not recorded in any part of the gut at all.

Eze and Ogbaran (2010) suggested that among the fungi, Aspergillus and Penicillium are biologically the most successful and are expected to occur in all sorts of habitats.

According to Rosas et al., (1992) Penicillium is one of the most common dominant species in tropical regions while Aspergillus is the most dominant throughout the world. This appears to be true in the present study also asAspergillus was the most dominant species followed by Penicillium.

As to the presence of fungi in fishes, literature reveals that many workers have identified several pathogenic fungi from different species of fish as well as fish eggs (Sati, 2002; Fraser et al., 1992; Roberts et al., 1993; Chinnabut et al., 1995; Mastan, 2008). Recently, Mastan (2016) while studying the fungal infection of fresh water fishes in Andhra Pradesh reported the presence of 17 species of fungi in 12 different types of fishes.

The presence of fungi highlights the need for immediate attention as fungal infections can be disastrous leading to collapse of the aquaculture industry. 


\section{References}

Ainsworth, G. C., Sparrow, F. K. and Sussman, A. S. (1973). A Taxonomic Review with Keys: Basidiomycetes and lower fungi. In: Ainsworth, G. C., Sparrow, F. K. and Sussman, A. S. (eds). The fungi, an advanced treatise, Vol. 4B Academic Press, Orlando.

Bangyeekhun, E. and Sylvie, M. A. (2001). Characterization of Saprolegnia sp. isolates from channel catfish. Dis.Aquat. Organ., 45: 53-59.

Barnett, H. L. (1962). Illustrated Genera of Imperfect Fungi. Burgess Publishing Co., p. 58.

Barnett, H. L. and Hunter, B. B. (1986). Illustrated genera of imperfect fungi. $4^{\text {th }}$ edn., Macmillan Publishing Company, p. 142.

Barron, G. L. (1986). The genera of Hyphomycetes from Soil. Williams and Wilkins, Baltimore. pp. 160.

Booth, C. (1977). Fusarium. Commonwealth Mycological Institute. Kew, Surrey, England.

Chinnabut, S., Roberts, R. J., Willoughby, L. G. and Pearson, M. D. (1995). Histopathology of snake head, Channastriatus (Bloch) experimentally infected with the specific Aphanomyces fungus associated with Epizootic Ulcerative Syndrome (EUS) at different temperatures. J. Fish Dis., 18: 41-47.

Chukanhom, K. and Hatai, K. (2004). Freshwater Oomycete isolated from eggs of the common carp (Cyprinus carpio) in Thailand. Mycoscience. 45: 42-48.

Domsch, K. H., Gams, W. and Anderson, T. H. (1980). Compendium of Soil Fungi. Academic Press, London, p. 48

Ellis, M. B. (1976). More Dematiaceous Hypomycetes. Commonwealth Mycological Institute Pub., Kew Surrey, England. p. 25.
Eze, V. C. and Ogbaran, I. O. (2010). Microbiological and Physico-chemical characteristics of fish pond water in Ughelli, Delta State Nigeria. Inter. J. Curr. Res., 8: 82-87.

Fraser, G. C., Callinan, R. B. and Calder, L. M. (1992). Aphanomycesspecies associated with red spot disease: an ulcerative disease of estuarine fish from eastern Australia. J. Fish Dis., 15: 173181.

Gillman, J. C. (1957). A Manual of Soil Fungi. Oxford and IBH Publishing Co., New Delhi. p. 250.

Mastan, S. A. (2008). Incidences of Dermatomycosis in fishes of Larpur reservoir, Bhopal, (M.P). J Herbal Med. Toxicol. 2: 37-40.

Meyer, F. P. (1991). Aquaculture disease and health management. J. Anim. Sci., 69: 4201-4208.

Ramaiah, N. (2006). A review on fungal diseases of algae, marine fishes, shrimps and corals. Indian J. Mar. Sci., 35: 380-387.

Raper, K. B. and Thom, C. (1949). A Manual of the Penicillia. Williams and Wilkins, Baltimore. p. 875.

Roberts, R.J., Willoughby, L.G., and Chinnabut, S. (1993). Mycotic aspects of Epizootic Ulcerative Syndrome (EUS) of Asianfishes. J. Fish Dis. 16: 169-183.

Rosas, I., Calderon, C., Escamilla, B. and Ulloa, M. (1992) Seasonal distribution of Aspergillus in the air of an urban area: Mexico City. Grana, 31: 315-319.

Sati, S. C. (2002). Conidal aquatic fungi of Nainital, Kumaun, Himalaya, India. Mycotaxon., 81: 445.

Schipper, M. A. A. (1984). A revision of the genus Rhizopus 1. The Rhstolonifergroup and Rh. oryzae. Stud. Mycol., 25: $1-19$.

Stolk, A. C. and Samson, R. A. (1983). The Ascomycetegenus Eupenicillium and 
related Penicillium anamorphs. Stud. Mycol. Baarn., 23: 1-149.

Subramanian, C. V. (1971). The Phialide. In Taxonomy of Fungi imperfecti. (B. Kendick (Ed.)), Toronto. University of Toronto Press. pp. 92-115.

Van der Plaats-Niterink, A. J. (1981).

Monograph of the Genus Pythium.
Studies in Mycology No. 21, Centraalbureau voor Schimmelculture. Baarn, The Netherlands.

Von Arx, J. A. (1981). The genera of fungi sporulating in pure culture. $3^{\text {rd }}$ edn. (J. Cramer, Vaduz, (ed.)), p. 424.

\section{How to cite this article:}

Balasubramanian, P. and Sivakami, R. 2018. An Analysis of the Commonly Occurring Fungal Populations in Water, Sediment and the Fish (Glossogobius giuris) at Lower Anicut, Thanjavur District, Tamil Nadu, India. Int.J.Curr.Microbiol.App.Sci. 7(07): 4174-4179. doi: https://doi.org/10.20546/ijcmas.2018.707.487 